\title{
Serum Zinc Levels in Egyptian Patients with HCV Induced Chronic Liver Diseases: Evaluation and Clinical Significance
}

\author{
Sabry A. Abdo ${ }^{1}$, Mostafa S. Elkady ${ }^{1}$, Hala M. El-Feky ${ }^{1}$, Aliaa A Shalaby ${ }^{2}$ \\ Mohamed L. Ajour ${ }^{1}$ \\ ${ }^{1}$ Hepatology, Gastroenterology and Infectious Diseases Department Faculty of Medicine, \\ Benha University, Benha, Egypt \\ ${ }^{2}$ Clinical and Chemical Pathology Department, National Research Centre,Cairo,Egypt
}

Corresponding Author Hala Mohammad El Feky

Mobile:

$+201006432009$

E mail: halaelfekynad@hotmail.com

Key words: Zinc; Hepatitis C; Chronic liver diseases
Background and study aim: HCV infection is a major health problem worldwide. In Egypt the estimated prevalence is about $22 \%$. As Zinc ( $\mathrm{Zn}$ ) is the second most prevalent trace element in the body, we aimed to evaluate serum $\mathrm{Zn}$ levels in patients with $\mathrm{HCV}$ induced chronic liver diseases, study the relationship between these levels and clinical profiles, histopathological criteria and HCC characters of the studied cases. Patients and Methods: Sixty nine patients aged from (18 to 67) years were included in addition to 23 age- and sex-matched healthy subjects serving as a control, all were stratified into, $G$ 1: 23 patients biopsy proven $\mathrm{CH}$. G 2: 23 cirrhosis patients. G 3 :23 HCC patients proved by abdominal ultrasonography, triphasic spiral C.T Scan and AFP. Group $4: 23$ healthy persons as controls. All underwent routine investigations and serum $\mathrm{Zn}$ levels were analyzed on atomic absorption spectrophotometer, meanwhile cirrhotic subjects were assessed for severity of disease by Child-Pugh classification.
Results: Serum zinc was significantly lower in chronic hepatitis than control on one hand and HCC group on the other hand $(\mathrm{p}<0.001)$ and they were significantly decreased in Child class $C$ patients than Child class A $(p=0.023)$. Significant positive correlation was found between serum $\mathrm{Zn}$ and age in cirrhotic group moreover, there was no significant correlation between serum $\mathrm{Zn}$ and any of laboratory parameters in the studied groups and fibrosis stages of chronic hepatitis group. Negative correlation was detected between serum $\mathrm{Zn}$ and tumor multiplicity and BCLC in HCC group. Conclusion:We can conclude that serum zinc decreased significantly in chronic $\mathrm{HCV}$ patients and these levels decreased by increasing severity of liver disease according to Child classification. It is recommended to evaluate the role of zinc supplementation in treating clinical manifestation of liver cirrhosis and liver cell failure due to $\mathrm{HCV}$.

\section{INTRODUCTION}

Hepatitis $\mathrm{C}$ virus (HCV) is a major cause of acute and chronic liver disease. $\mathrm{HCV}$ infection frequently leads to chronic hepatitis aggravated by hepatic fibrosis and steatosis subsequently leads to increase the risk of hepatic cirrhosis and hepatocellular carcinoma that are responsible for high morbidity and mortality rate [1]. In Egypt, HCV infection is a major health problem. According to World Health Organization (WHO), the estimated prevalence is about $22 \%$ [2], because of the very high prevalence rate of $\mathrm{HCV}$ in the general Egyptian population, it accounts for most chronic liver diseases and HCC cases in Egypt [3].

Trace metals are integral part of metalloenzymes and participate in biological functions, such as oxygen transport, free radical scavenging, structural organization of macromolecules, and hormonal activity [3]. Zinc $(\mathrm{Zn})$ is the second most prevalent trace element in the body. It is integrally involved in the normal life cycle and it has many important regulatory, catalytic, and defensive functions [4]. Acute and chronic viral 
hepatitis are associated with reduced serum zinc levels, without any difference among groups classified according to the etiology or the clinical course of liver disease and the linkage between zinc homeostasis and viral infection could be identified with the assumption that viruses produce severe oxidative stress in the hepatocytes, leading to apoptosis or hepatocytic necrosis and causing a decrease in protein synthesis [6]. The low serum zinc level is common in patients with liver cirrhosis (due to decreased intake, decreased absorption, decreased bioavailability, and increased losses (because of malabsorption) [5], HCC and in HCC tumor tissue [7]. The decrease in intracellular zinc levels in HCC could be explained by a down regulation of ZIP14 gene expression and the near absence of the protein within hepatoma cells in core biopsy samples. ZIP14 localizes to the cell membrane of normal hepatocytes and is a functional transmembrane transporter involved in the uptake of zinc into the cell [8]. In this study, we evaluated serum zinc levels in patients with HCV induced chronic hepatitis, Liver cirrhosis, and HCC and studied the relationship between these levels and clinical profiles, histopathological criteria and HCC characters of the studied cases.

\section{SUBJECTS AND METHODS}

This cross-sectional study was conducted on 69 adult patients with HCV-related chronic liver diseases who were referred to Hepatology, Gastroenterology and Infectious diseases department, Benha University Hospital during the period from August 2013 to April 2014. Twenty three healthy, age and sex matched subjects were selected as controls. An informed medical consents was taken for their participation in the study. The protocol of the study was approved by the human ethical committee of Benha University Hospital. Patients with diseases affecting serum zinc levels such as renal impairment and chronic heart failure, alcohol abuse, diabetes mellitus, previous antiviral treatment, concurrent infections or malignancy other than HCC, chronic HBV infection or concomitant chronic HBV and HCV infections, zinc therapy or using hormonal drugs was excluded in addition to patients subjected to surgery or chemotherapy.

The Studied subjects were stratified into : Group 1 (chronic hepatitis group) that included 23 patients who were diagnosed by liver biopsy. Group2 (cirrhotic group) that included 23 patients in whom cirrhosis was diagnosed by clinical, laboratory data and ultrasonographic examination. Group 3 (HCC group) that included 23 patients with $\mathrm{HCV}$ related $\mathrm{HCC}$ who were diagnosed by abdominal ultrasonography, triphasic C.T and AFP. Group 4 (control group) that included 23 healthy persons as a control group with no clinical, laboratory or ultrasonographic evidence of illness.

All subjects underwent CBC, liver profile (ALT, AST, and bilirubin using Beckman Synchron CX7 Delta Clinical System, prothrombin time, and INR using stago analyzer), Serum creatinine, Viral markers including : HCV-Ab by Enzyme linked immunosorbent assay (ELISA) (IU/ml) in addition to HBsAg by ELISA (IU/ml), and AFP. Abdominal ultrasonography, abdominal triphasic spiral C.T Scan was done for HCC group. The severity of liver cirrhosis was assessed by ChildPugh score and Barcelona Clinic Liver Cancer (BCLC) staging system was done for HCC group.

Sample preparation: Blood samples were collected under aseptic conditions, then samples protected in evacuated tubes without adding any anticoagulant agent. The samples were left standing for one hour; sera were separated at $3000 \mathrm{rpm}$ centrifugation for $10 \mathrm{~min}$ and preserved at $-20^{\circ} \mathrm{C}$ till further analysis.

\section{Method of serum $\mathrm{Zn}$ assay:}

The sera were diluted 1: 5 with double deionised water. $\mathrm{Zn}$ levels were detected by atomic absorption spectrophotometer instrument (Variant Australia) using internal standard (Merck Germany), then the results were multiplied by 5 . Normal range of serum $\mathrm{Zn}$ is $(0.8-1.5 \mu \mathrm{g} / \mathrm{ml})$.

\section{Statistical analysis: \\ Sample size calculation:}

Sample size was 92 subjects (69 cases and 23 controls). The $\alpha$ level was 0.05 as it represents the type I error probability for a two sided test. The sample size was calculated at $95 \%$ confidence level (CL) and power of the study $80 \%$. $\mathrm{Z}$ value was 1.96 at $95 \%$ CL.

The collected data were tabulated and analyzed using SPSS version 16 software (Spss Inc, Chicago, ILL Company). Statistical analysis was done according to Knapp and Miller [9].

Categorical data were presented as number and percentages while quantitative data were expressed as mean and standard deviation, median range. Chi square test $\left(\mathrm{X}^{2}\right)$, Fisher's, ANOVA (F test), student "t", Man Whitney U test, Krauskal Wallis 
test and Spearman's correlation coefficient (rho) were used as tests of significance.

\section{RESULTS}

Patients of HCC group were significantly older than those of chronic hepatitis and cirrhotic groups $(\mathrm{P}<0.001)$. There was no statistically significant difference between the studied groups regarding gender. Serum zinc levels were significantly lower in chronic hepatitis group than control group and HCC group $(\mathrm{P}<0.001)$. Patients with Child class (C) had lower serum Zn levels than those with Child class (A) with significant difference between them $(\mathrm{P}=0.023)$. Out of 23
HCC patients, 1 patient (4.3\%) had stage 0 of BCLC, 12 patients $(52.3 \%)$ had stage A, 5 patients $(21.7 \%)$ had stage B, 1 patient $(4.3 \%)$ had stage C, 4 patients (17.4\%) had stage D.

Significant positive correlation was found between serum $\mathrm{Zn}$ levels and age in cirrhotic group but there was no significant correlation between serum $\mathrm{Zn}$ levels and any of laboratory parameters of the studied groups on one hand and fibrosis stages of chronic hepatitis group on the other hand. Negative non significant correlation was detected between serum $\mathrm{Zn}$ levels and tumor multiplicity and BCLC in HCC group.

Table (1): Demographic criteria of the studied groups

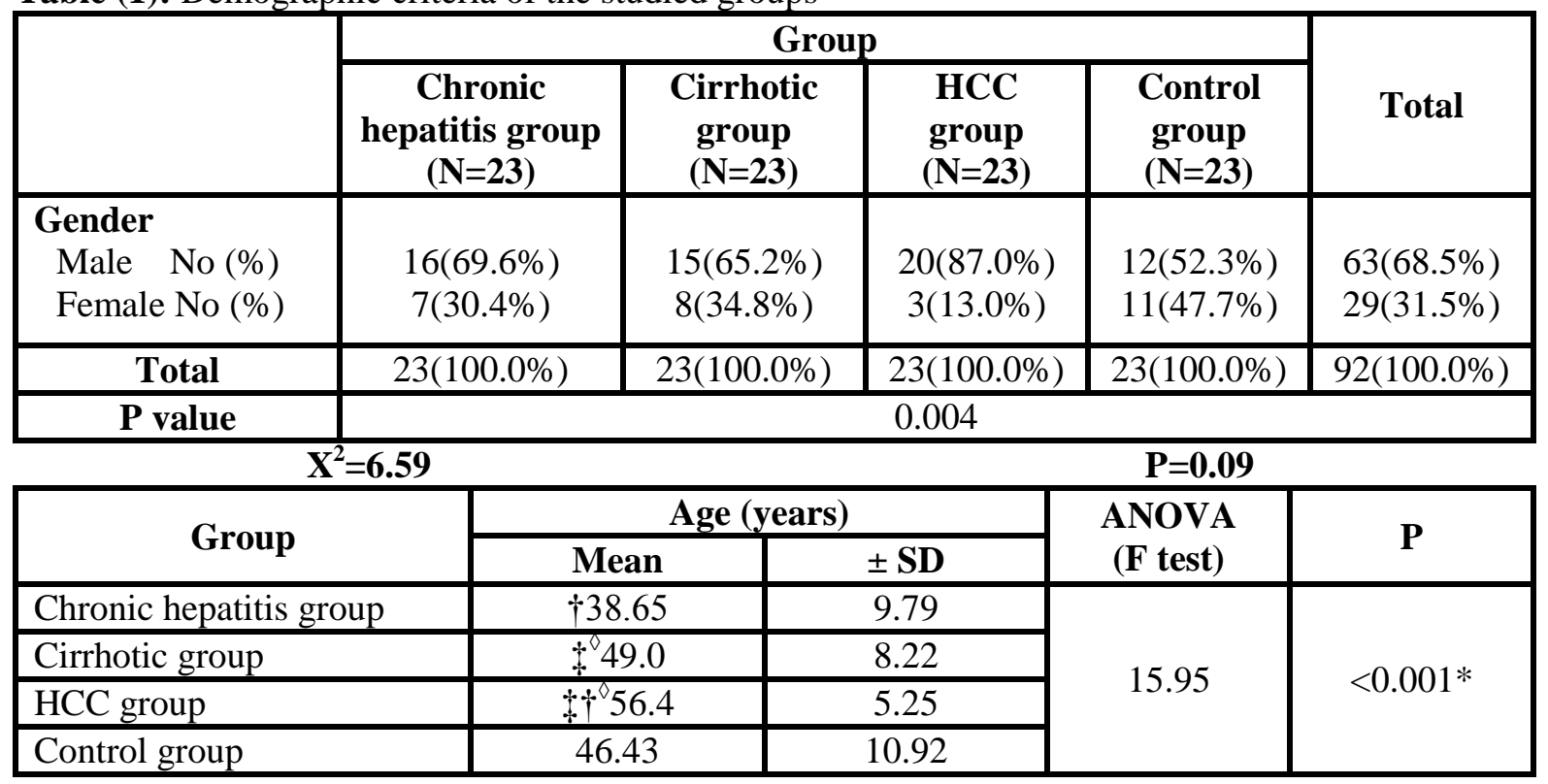


Table (2): Laboratory criteria of the studied groups

\begin{tabular}{|c|c|c|c|c|c|c|c|c|c|c|c|c|}
\hline \multirow[t]{2}{*}{ Variable } & \multicolumn{2}{|c|}{$\begin{array}{l}\text { Chronic hepatitis } \\
\text { group } \\
(\mathbf{N}=\mathbf{2 3})\end{array}$} & \multicolumn{2}{|c|}{$\begin{array}{l}\text { Cirrhotic group } \\
\qquad(\mathbf{N}=\mathbf{2 3})\end{array}$} & \multicolumn{2}{|c|}{$\begin{array}{l}\text { HCC group } \\
(\mathbf{N}=\mathbf{2 3})\end{array}$} & \multicolumn{2}{|c|}{$\begin{array}{l}\text { Control group } \\
(\mathbf{N}=\mathbf{2 3})\end{array}$} & \multirow[t]{2}{*}{$\mathbf{P}$} & \multirow[t]{2}{*}{$\begin{array}{c}F \\
\text { test }\end{array}$} & \multirow{2}{*}{$\begin{array}{c}\text { Kraus } \\
\text { kal } \\
\text { Wallis } \\
\text { test }\end{array}$} & \multirow{2}{*}{$\begin{array}{l}\longleftarrow \\
\vdots \\
z \\
2\end{array}$} \\
\hline & Mean & $\pm \mathrm{SD}$ & Mean & \pm SD & Mean & \pm SD & Mean & $\pm \mathrm{SD}$ & & & & \\
\hline $\begin{array}{c}\text { Haemoglobin } \\
\text { (g/dl) }\end{array}$ & 13.87 & 1.316 & $\$ 12.72$ & 1.303 & $\$ 12.03$ & 1.319 & 13.00 & 1.421 & $<0.001 *$ & 7.48 & & \\
\hline WBCs $\left(\times 10^{3}\right)$ & 6.31 & 2.041 & 5.93 & 1.295 & 5.28 & 1.640 & 7.58 & 2.031 & 0.26 & 6.84 & & \\
\hline PLT $\left(\times 10^{3}\right)$ & 204.7 & 48.076 & $\dagger+113.7$ & 51.038 & $\dagger+124.2$ & 58.141 & 246.5 & 63.880 & $<0.001^{*}$ & 30.5 & & \\
\hline ALT (U/L) & $\dagger 62.20$ & 60.278 & 50.91 & 46.497 & 51.86 & 24.074 & 31.60 & 12.276 & $0.01 *$ & & 11.5 & \\
\hline AST (U/L) & 58.30 & 56.840 & 48.43 & 35.279 & $\dagger 66.08$ & 39.485 & 34.52 & 12.474 & $0.001^{*}$ & & 15.8 & \\
\hline $\begin{array}{l}\text { Total bilirubin } \\
\text { (mg/dl) }\end{array}$ & 0.62 & 0.380 & $\dagger 1.04$ & 0.651 & $\dagger+1.94$ & 0.870 & 0.52 & 0.244 & $<0.001^{*}$ & & 42.1 & \\
\hline $\begin{array}{c}\text { Serum albumin } \\
(\mathrm{gm} / \mathrm{dl})\end{array}$ & $\uparrow 4.43$ & 0.43 & $\dagger 3.83$ & 0.47 & $\dagger \$ \Delta 3.00$ & 0.53 & 4.03 & 0.38 & $<0.001 *$ & & $\begin{array}{c}\mathrm{F} \text { test }= \\
39.5\end{array}$ & \\
\hline $\begin{array}{c}\alpha \text {-feto protein } \\
(\text { ng/ml) }\end{array}$ & $\diamond 4.52$ & 3.14201 & $\diamond 44.44$ & 61.63213 & 1422.86 & 2124.48964 & $\diamond 7.30$ & 3.84282 & $<0.001 *$ & & 52.2 & \\
\hline $\begin{array}{c}\text { Serum } \\
\text { creatinine } \\
(\mathrm{mg} / \mathrm{dl}\end{array}$ & 0.937 & 0.202 & 1.013 & 0.225 & 1.009 & 0.258 & 1.011 & 0.250 & 0.64 & & & 0.56 \\
\hline PC (\%) & 89.8 & 8.61 & $\dagger+76.8$ & 10.36 & $+\$ \Delta 65.2$ & 13.45 & 92.1 & 5.47 & $<0.001 *$ & & & 36.6 \\
\hline INR & 1.11 & 0.113 & $+\$ 1.26$ & 0.204 & $\dagger+\Delta 1.49$ & 0.306 & 1.07 & 0.059 & $0.001 *$ & & & 5.78 \\
\hline PT (second) & 12.75 & 1.423 & $\dagger 13.22$ & 1.388 & $\dagger+\Delta 14.71$ & 2.00 & 11.84 & 0.427 & $<0.001^{*}$ & & & 16.2 \\
\hline
\end{tabular}

Table (3): Mean and standard deviation of serum zinc levels among the studied groups

\begin{tabular}{|l|c|c|c|c|}
\hline \multirow{2}{*}{\multicolumn{1}{|c|}{ Group }} & \multicolumn{2}{|c|}{ Serum Zn $(\boldsymbol{\mu g} / \mathbf{m l})$} & \multirow{2}{*}{$\begin{array}{c}\text { Krauskal Wallis } \\
\text { test }\end{array}$} & \multirow{2}{*}{ P } \\
\cline { 2 - 3 } & Mean & \pm SD & \multirow{2}{*}{25.25} & $<0.001^{*}$ \\
\hline Chronic hepatitis group & $\dagger \diamond 0.56$ & 0.246 & & \\
\hline Cirrhotic group & 0.87 & 0.236 & & \\
\hline HCC group & 0.97 & 0.482 & & \\
\hline Control group & 1.15 & 0.40 & & \\
\hline
\end{tabular}

Table (4): Number and percent of studied cases within each group according to serum $\mathrm{Zn}$ levels

\begin{tabular}{|l|c|c|c|}
\hline \multicolumn{1}{|c|}{ Group } & Low Zn levels cases & Normal Zn levels cases & High Zn levels case \\
\hline Chronic hepatitis group & $19(82.7 \%)$ & $3(13 \%)$ & $1(4.3 \%)$ \\
\hline Cirrhotic group & $15(65.2 \%)$ & $4(17.4 \%)$ & $4(17.4 \%)$ \\
\hline HCC group & $7(30.4 \%)$ & $7(30.4 \%)$ & $9(39.2 \%)$ \\
\hline
\end{tabular}


Table (5): Spearman's correlation coefficient between mean serum $\mathrm{Zn}$ levels and age and some laboratory parameters of the studied groups

\begin{tabular}{|c|c|c|c|c|c|c|c|c|}
\hline \multirow{3}{*}{ With } & \multicolumn{8}{|c|}{ Serum Zn $(\mu \mathrm{g} / \mathrm{ml})$} \\
\hline & \multicolumn{2}{|c|}{$\begin{array}{c}\text { Chronic } \\
\text { hepatitis group }\end{array}$} & \multicolumn{2}{|c|}{$\begin{array}{c}\text { Cirrhotic } \\
\text { group }\end{array}$} & \multicolumn{2}{|c|}{ HCC group } & \multicolumn{2}{|c|}{ Control group } \\
\hline & Rho & $\mathbf{P}$ & Rho & $\mathbf{P}$ & Rho & $\mathbf{P}$ & Rho & $\mathbf{P}$ \\
\hline Age (years) & 0.328 & 0.12 & 0.499 & $0.015^{*}$ & 0.317 & 0.14 & 0.630 & $0.001^{*}$ \\
\hline Haemoglobin(g/dl) & -0.233 & 0.28 & -0.134 & 0.54 & 0.059 & 0.79 & -0.133 & 0.54 \\
\hline WBCs $\left(\times 10^{3}\right)(\mathrm{C} / \mathrm{mm} 3)$ & 0.393 & 0.06 & 0.117 & 0.59 & 0.192 & 0.38 & 0.343 & 0.11 \\
\hline Platelet $\left(\mathrm{x} 10^{3}\right)(\mathrm{C} / \mathrm{mm} 3)$ & 0.277 & 0.2 & 0.0 & 1.0 & 0.326 & 0.12 & 0.08 & 0.72 \\
\hline $\mathrm{ALT}(\mathrm{U} / \mathrm{L})$ & -0.156 & 0.47 & -0.039 & 0.85 & -0.159 & 0.46 & -0.171 & 0.43 \\
\hline AST(U/L) & -0.001 & 0.99 & -0.038 & 0.86 & 0.022 & 0.92 & 0.233 & 0.28 \\
\hline T. bilirubin(mg/dl) & 0.064 & 0.77 & 0.205 & 0.34 & 0.223 & 0.31 & 0.124 & 0.57 \\
\hline $\operatorname{Albumin}(\mathrm{mg} / \mathrm{dl})$ & 0.155 & 0.48 & 0.038 & 0.86 & 0.180 & 0.41 & 0.043 & 0.84 \\
\hline PT(second) & 0.007 & 0.97 & 0.204 & 0.35 & 0.149 & 0.49 & -0.259 & 0.23 \\
\hline $\mathrm{PC}(\%)$ & -0.095 & 0.66 & -0.141 & 0.52 & -0.164 & 0.45 & 0.259 & 0.23 \\
\hline INR & 0.06 & 0.78 & 0.197 & 0.36 & 0.132 & 0.54 & -0.266 & 0.21 \\
\hline S. Creatinine $(\mathrm{mg} / \mathrm{dl})$ & 0.226 & 0.3 & 0.082 & 0.71 & 0.186 & 0.39 & 0.356 & 0.096 \\
\hline $\mathrm{AFP}(\mathrm{ng} / \mathrm{ml})$ & 0.071 & 0.74 & 0.235 & 0.28 & 0.291 & 0.17 & -0.286 & 0.18 \\
\hline F stage & 0.08 & 0.72 & ----- & $\begin{array}{l}---- \\
\end{array}$ & ----- & $\overline{-----}$ & ----- & $\begin{array}{l}---- \\
\end{array}$ \\
\hline
\end{tabular}

Table (6): Among Correlation between serum Zn levels and some studied variables HCC group

\begin{tabular}{|l|c|c|}
\hline \multirow{2}{*}{ With } & \multicolumn{2}{|c|}{ Serum Zn $(\boldsymbol{\mu g} / \mathbf{m l})$} \\
\cline { 2 - 3 } & Rho & P \\
\hline Tumor size & 0.358 & 0.093 \\
\hline Tumor multiplicity & -0.043 & 0.84 \\
\hline BCLC staging & -0.307 & 0.15 \\
\hline
\end{tabular}

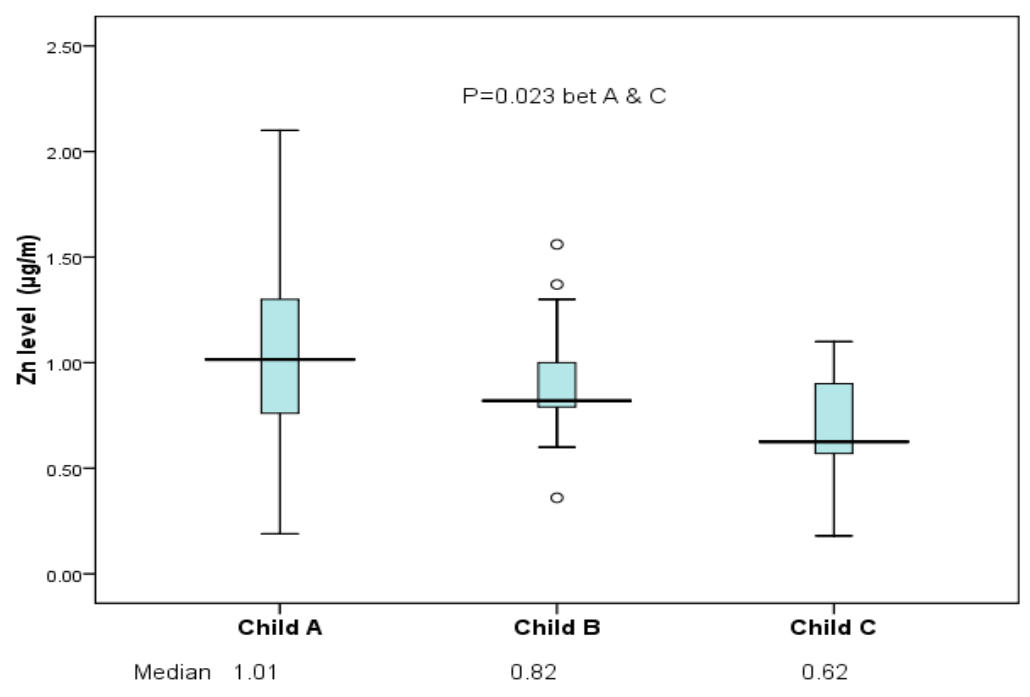

Figure (1): Serum $\mathrm{Zn}$ levels according to Modified Child-Turcotte- Pugh scoring system 


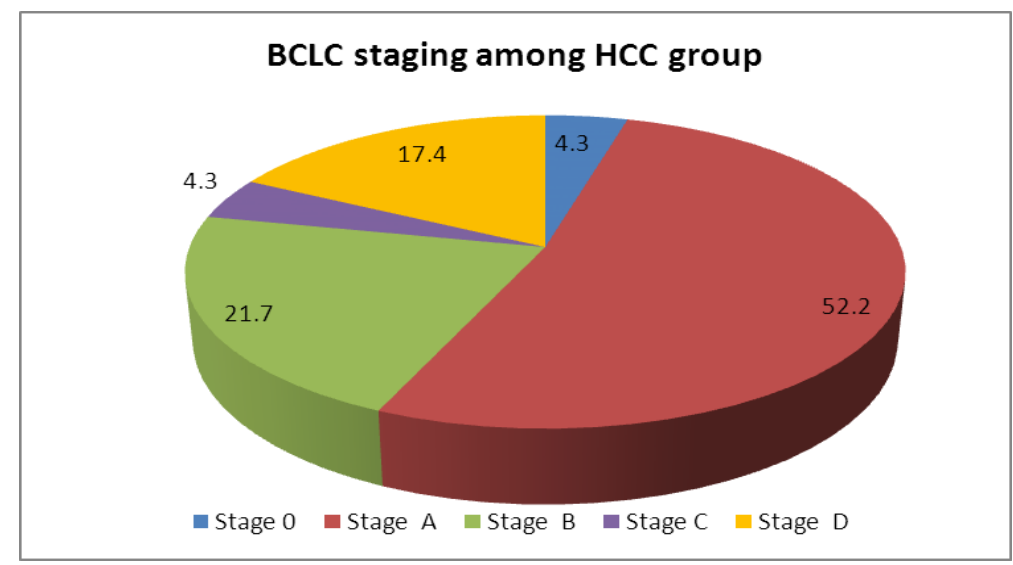

Figure (2): BCLC staging among HCC group

\section{DISCUSSION}

Hepatitis $\mathrm{C}$ virus infection is one of the main causes of chronic liver disease worldwide in addition the long-term impact of its infection is highly variable, from minimal changes to extensive fibrosis and cirrhosis with or without hepatocellular carcinoma [10]. In the present study, patients of HCC group were significantly older than those of chronic hepatitis and cirrhotic groups $(p<0.001)$. This result was similar to that found by Wang et al. [11] and El-Zayadi et al. [12]; where the latter reported that $\mathrm{HCC}$ in Egypt is significantly more prevalent among older age groups than younger age groups and suggested that $\mathrm{HCV}$ infection in old patients induces a rapid progression to $\mathrm{HCC}$ independent of $\mathrm{HCV}$ genotype. Old age is a risk factor for $\mathrm{HCC}$, especially in areas where $\mathrm{HCV}$ infection is endemic as Egypt [13]. Regarding sex distribution among patients of the current work, there was a High percentage of males in all groups. In agreement with our results, Johnson et al. [14] reported that males had higher rate of cirrhosis than females. Male to female ratio differs among countries as greater ratios were noticed in the high incidence regions such as Africa, China, Taiwan and Japan [15]. This finding may be attributed to more exposure to risk factors like $\mathrm{HCV}$ among male patients. However, sex hormones and other $\mathrm{x}$-linked genetic factors may also be important role [12]. The current study reported that there was significant decrease in the mean serum $\mathrm{Zn}$ levels in chronic hepatitis group compared to control and HCC group $(\mathrm{p}<0.001)$. This finding agreed with Nakayama et al. [16] and Ko et al. [17] who reported that serum zinc levels was significantly lower in chronic hepatitis patients than in healthy controls. However, Saghir et al. [18] stated that there was no any statistically significant difference between chronic hepatitis $\mathrm{C}$ patients and controls according to serum zinc and copper concentrations. The difference may be attributed to different sample sizes (as the previous study included 71 cases for each group). However Moriyama et al. [19] elicited that the median zinc concentration in the HCC with liver cirrhosis group (68 patients) was significantly lower than those in the chronic hepatitis group, a result that was against that of the current study. The results of the current study may be explained by the fact that high level of IL6 that occurs in response to acute inflammation and infection causes induction of ZIp14, which is $\mathrm{Zn}$ transporter, resulting in uptake of zinc into liver and serum hypozincemia associated with inflammation and infection [20,21]. The current work revealed that in chronic hepatitis, cirrhotic and HCC groups : 19 cases $(82.7 \%)$, 15cases $(65.2 \%)$ and 7 cases $(30.4 \%)$ had low serum $\mathrm{Zn}$ levels while 3 cases $(13 \%), 4$ cases $(17.4 \%)$ and 7 cases $(30.4 \%)$ had normal serum $\mathrm{Zn}$ levels and lastly 1 case $(4.3 \%), 4$ cases $(17.4 \%)$ and 9 cases (39.1\%) had high serum $\mathrm{Zn}$ levels respectively. Port et al. [22] assessed serum zinc levels in 22 HCV-related HCC patients and they found that 7 $(31.8 \%), 14(63.6 \%)$ and $1(4.5 \%)$ of patients were below upper limit of normal, normal and above upper limit of normal, respectively. Also Atia et al. [23] revealed that among the total of 50 cirrhotic patients $36(72 \%)$ had low serum zinc levels while remaining $14(28 \%)$ patients had normal serum zinc levels. The results obtained in this work showed that the mean of serum zinc levels was significantly lower in patients with 
Child class $\mathrm{C}$ than those with Child class A ( $\mathrm{P}=$ 0.023 ), a result that came in agreement with Moriyama et al. [19] and Vijaylaxmi et al. [24] who found that the median zinc concentration in the Child-Pugh $\mathrm{C}$ group was significantly lower than those in the Child A $(\mathrm{P}<0.0001)$ and Child $\mathrm{B}(\mathrm{P}=0.0033)$ classes and that serum zinc levels were significantly decreased with advancement of liver disease as compared to early stage of liver cirrhosis with significant negative correlation with

Child-Pugh Score. Significant positive correlation between serum $\mathrm{Zn}$ levels and age in cirrhotic group was observed in the current work, meanwhile there was no Significant correlation between serum $\mathrm{Zn}$ levels and any of the other laboratory parameters of the studied groups and fibrosis stages of chronic hepatitis group. These results came on line with El Bassuoni et al. [7] and Anber et al. [25] who found no significant correlations when serum $\mathrm{Zn}$ levels were correlated with ALT, AST, total bilirubin, INR, $\alpha$-feto protein, serum albumin, haemoglobin $\%$ and WBCs count. On the other hand Moriyama et al. [19] reported highly significant positive correlation between serum $\mathrm{Zn}$ levels and haemoglobin \%, platelets count, WBCs count and serum albumin in chronic hepatitis and liver cirrhosis groups and a highly significant negative correlation between serum $\mathrm{Zn}$ levels and $\alpha$-feto protein, total bilirubin and AST level. Also the present study showed that there was no significant correlation between serum $\mathrm{Zn}$ levels and BCLC staging $(\mathrm{P}=0.15)$, tumor size $(\mathrm{P}=$ $0.093)$ and multiplicity $(\mathrm{P}=0.84)$ of $\mathrm{HCC}$ group. The same results were reported by Moriyama et al. [19] who stated that the size and numbers of cancerous nodules were not correlated with the serum concentration of zinc or with BCLC staging system.

Funding: None.

Conflicts of interest: None.

Ethical approval:Approved.

\section{REFERENCES}

1. Umemura T, Ichijo T, Yoshizawa K, Tanaka E, Kiyosawa K. Epidemiology of hepatocellular carcinoma in Japan. J. Gastroenterol; 2009, 44 (suppl. 19), 102-107.

2. Ford N, Kirby C, Singh K, Mills EJ, Cooke G, Kamarulzaman A, et al. Chronic hepatitis C treatment outcomes in low- and middle-income countries: a systematic review and meta-analysis. Bull World Health Organ; 2012. 90(7): 540-550.
3. Saghir M, Shaheen N, Shah MH. Comparative Evaluation of Trace Metals in the Blood of Hepatitis C Patients and Healthy Donors. Biol Trace Elem Res.; 2011, 143: 751-763.

4. Mohammad MK, Zhou Z, Cave M, Barve A, McClain CJ. Zinc and liver disease. Nutr. Clin. Pract.; 2012, (27): 8-20.

5. Maret W. Cellular zinc and redox states converge in the metallothionein/thionein pair. J Nutr 2003; 133(5 Suppl. 1):1460S-62S.

6. Kalkan A, Bulut V, Avci S, Celik I, Bingol NK. Trace elements in viral hepatitis. J. Trace Elem. Med. Biol.; 2002, 16 (4): 227-230.

7. El Bassuoni MA, Talaat RM, Mahfouz, RG. Serum Level of Some Trace Elements as Prognostic Factors in Egyptian Patients with HCV-related Liver Disease. Egyptian Journal of Medical Microbiology, 2009, Vol. 18, No. 2.

8. Franklin RB, Costello LC. Zinc as an anti-tumor agent in prostate cancer and in other cancers. Arch Biochem Biophys.; 2007, 463: 211-217.

9. Knapp, RG, Miller MC. Clinical Epidemiology and Biostatistics. National Medical Series (NMS) from Williams and Wilkins, 1992.

10. Mutimer D, Aghemo A, Diepolder H, Negro F, Robaeys G, Ryder S, et al. EASL Clinical Practice Guidelines: Management of hepatitis C virus infection. Journal of Hepatology; 2014, Vol. 60:392-420.

11. Wang-Sheng KO, Chih-Hung GU, Ozen H. Blood micronutrient, oxidative stress, and viral load in patients with chronic hepatitis C. World $J$ Gastroenterol. 2005; 30:4697-702.

12. El-Zayadi A, Badran H, Barakat E. Hepatocellular carcinoma in Egypt: a single center study over decade. World J Gastroenterol. 2005; 11(33):5193-8.

13. Omata M, Lesmana LA, Tateishi R, Chen PJ, Lin SM, Yoshida H, et al. Asian Pacific Association for the Study of the Liver consensus recommendations on hepatocellular carcinoma. Hepatol Int. 2010; 4:439-74.

14. Johnson PE, Hunt CD, Milne DB. Zinc excretion and balance in men fed diets low in Zinc. Am J Clin Nutr. 2003; 57:557-65.

15. El-Serag H. Epidemiology of viral hepatitis and hepatocellular carcinoma. Gastroenterology. 2012; 142(6):1264-73.

16. Nakayama A, Fukuda H, Ebara M, Hamasaki H, Nakajima K, Sakurai H. A new diagnostic method for chronic hepatitis, liver cirrhosis, and hepatocellular carcinoma based on serum 
metallothionein, copper, and zinc levels. Biol Pharm Bull.; 2002, 25(4): 426-431.

17. Ko W, Guo C, Hsu G, Chiou YL, Yeh MS, Yaun SR. The effect of zinc supplementation on the treatment of chronic hepatitis $\mathrm{C}$ patients with interferon and ribavirin. Clin Biochem.; 2005, 38(7):614-20.

18. Saghir, M, Shaheen N, Shah, MH. Comparative Evaluation of Trace Metals in the Blood of Hepatitis C Patients and Healthy Donors. Biol Trace Elem Res. 2011; 143: 751-763.

19. Moriyama M, Matsumura H, Fukushima A, Ohkido K, Arakawa Y, Nirei K et al. Clinical Significance of Evaluation of Serum Zinc Concentrations in C-Viral Chronic Liver Disease. Dig Dis Sci.; 2006, 51: 1967-1977.

20. Taylor KM, Morgan HE, Johnson A, Nicholson RI. Structure- function analysis of a novel member of the LIV-1 subfamily of zinc transporters, ZIP14, FEBS Lett.; 2005, 579: 427 432.
21. Lichten LA, Cousins RJ. Mammalian zinc transporters: nutritional and physiologic regulation. Annu Rev Nutr.; 2009, 29:153-76.

22. Port GZ, Oliveira K, Soldera J, Tovo CV. Biochemical nutritional profile of liver cirrhosis patients with hepatocellular carcinoma. Arq. Gastroenterol. 2014, Vol. 51 no.1.

23. Atia F, sultana N, Ahmed S, Ferdous S, sultana R, Atiquzzaman M. A Study of Serum Zinc level in Cirrhosis of Liver. Bangladesh J Med Biochem 2012; 5(2): 44-47.

24. Nangliya V, Sharma A, Yadav D, Sunder S, Nijhawan S, Mishra S. Study of Trace Elements in Liver Cirrhosis Patients and Their Role in Prognosis of Disease. Biological Trace Element Research. 2015; 165(1): 35-40.

25. Anber NH, EL-Ghannam MZ, El-Kheshen GA, Bialy MI. Evaluation of serum zinc level in Egyptian patients with hepatitis C-associated cirrhosis. J Pharm Biomed Sci; 2016, 06(02):8185 . 